\title{
The Geological History of the Maidenhair Tree and its Allies
}

\author{
By Sir Albert Seward, F.R.S.
}

$I^{\mathrm{T}}$ is probably true to say that Ginkgo biloba, the maidenhair tree, is the most interesting and impressive link with the past in the plant kingdom. Does it still exist as a wild tree? Most botanists would probably answer that far-travelled plant collectors in China have never seen a maidenhair tree growing under conditions in which man was not involved. It would, however, be rash definitely to assert that the question is settled. In 1933, a Chinese botanist, W. C. Cheng', after recording the occurrence of Ginkgo in certain localities in the Chekiang province, added: "This tree is very common in Tienmu-Shan, growing in association with coniferous and broad-leaved trees. It seems to grow spontaneously in that region." The word "seems" implies a lack of conviction. It may still be true to say that Ginkgo would have ceased to exist centuries ago had not man adopted it as an object of religious veneration and carefully tended it in the groves of temples and other favoured places.

This sacred tree is an isolated and primitive type ; the solitary living representative of a comparatively large family distinguished by certain important peculiarities from other families of naked-seeded plants. About forty years ago, Ginkgo was removed from its former association with the yew among the Conifers and placed in a separate family, the Ginkgoaceæ, and even in a group of its own, the Ginkgoales. Ginkgoalean trees were formerly almost cosmopolitan; and there were many genera.

My present purpose is neither to follow through the ages the gradual rise into prominence of the Ginkgoales, nor to attempt a description of the wanderings of the several genera over the world's surface ; it is simply to direct attention to some recent work which has greatly extended our knowledge of ginkgoalean trees in Arctic floras separated in time from the present by at least one hundred million years and more. It has long been known that Ginkgo and other members of the family were common trees in arctic lands, and flourished so far north as $80^{\circ} \mathrm{N}$. lat. Professor Nathorst of Stockholm, writing in 1911, spoke of fossil leaves of a Ginkgo covering the surface of Lower Cretaceous shale in Spitsbergen as completely as the leaves cover the soil beneath a living Gingko tree in autumn.

The first contribution to be briefly considered is by Dr. Rudolf Florin of Stockholm, the author of a well-illustrated paper entitled "Die fossilen Ginkgophyten von Franz-Joseph-Land nebst Erörterungen über vermeintliche Cordaitales Mesozoischen Alters", Some of Dr. Florin's conclusions, which are of minor importance and do not affect the soundness of the work as a whole, may be questioned; but all botanists who regard the past history of recent genera as worthy of attention will heartily welcome this very valuable contribution from a leading expert in a special branch of palæobotanical research.

We are concerned only with the Ginkgoales. Improvement in methods of examining fossil leaves microscopically has greatly facilitated the discovery of more trustworthy evidence of natural affinity. It is seldom possible to cut microtome sections of petrified leaves or other plant remains, but Dr. Florin has succeeded in doing this with some of the Franz-Josef Land material after treatment with hydrofluoric acid. Petrified plants are relatively rare, and most fossil leaves occur as thin carbonized films on the surface of shale and sandstone. By the employment of a suitable technique, Florin and other palæobotanists have made substantial additions to a more exact knowledge of the histological structure of epidermal layers, which throws welcome light on relationship to recent plants.

Dr. Florin's paper is mainly devoted to an intensive and comparative study of ginkgoalean leaves from rocks of Lower Cretaceous age, approximately contemporaneous with the Wealden beds of south-eastern England. In 1880, Mr. Leigh Smith collected a few fossil plants in Franz-Josef Land : a larger collection was brought to England in 1896 in the steamship Windward chartered by the Jackson-Harmsworth Expedition. The plants were partially described in 1897 by Messrs. E. T. Newton and J. J. H. Teall : specimens collected by Dr. Nansen were described by Prof. Nathorst, and others by Graf zu Solms-Laubach. These descriptions have now been revised and greatly supplemented by Florin. The best material was found on the southern coast of the archipelago, where horizontal layers of basaltic lava, thickly covered with ice, overlie a few hundred feet of sedimentary rocks. These early Cretaceous plants afford a striking contrast to the few flowering plants, barely thirty in number, which are now able to withstand the long arctic night. There were trees in those days, and a flora clearly demanding much more genial climatic conditions. 
The genus Ginkgo was represented by two, possibly more, species : Ginkgo polaris, originally described by Nathorst, with small semicircular leaves about $3.5 \mathrm{~cm}$. broad and $2.5 \mathrm{~cm}$. long, more or less deeply dissected into linear or wedgeshaped segments comparable on a smaller scale to the lobed leaves of the maidenhair tree borne on young shoots and seedlings. In venation and in the minute structure of the stomata and other epidermal cells, the arctic leaves closely resemble those of Ginkgo biloba. Another closely allied species is G. coriacea Florin. Some seeds from the same beds revealed epidermal characters similar to those of the leaves. The most important part

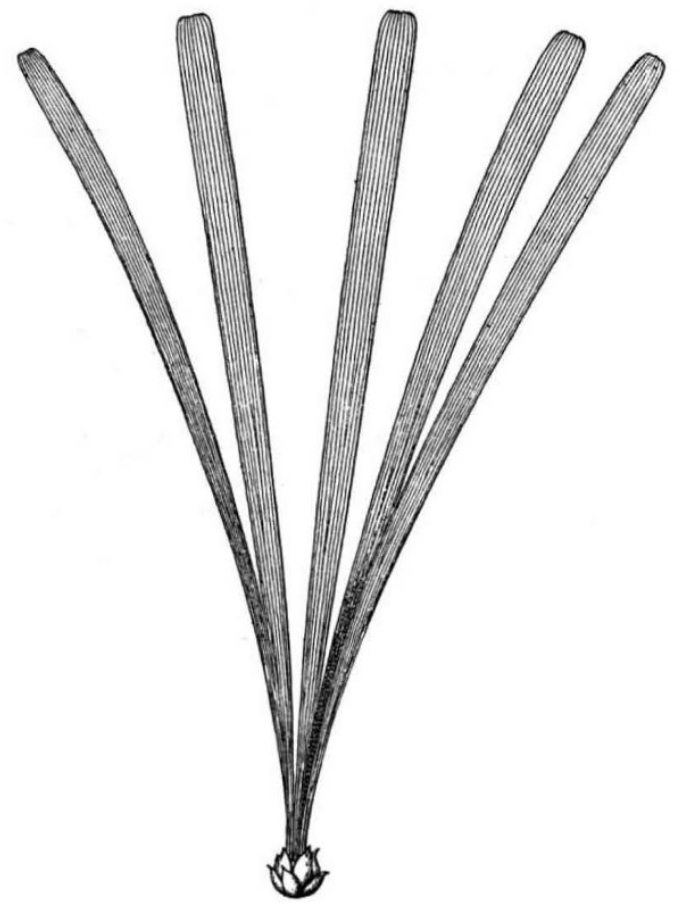

Fig. 1.

Windwardia Crookallii Florin. ReCONSTRUCtion OF A SINGLE DWARF SHOOT. 3 NAT. SIZE. AFTER R. FLORIN.

of Florin's paper is the description of other genera of the Ginkgo family differing from the maidenhair tree in bearing long and narrow leaves in tufts on very short, deciduous branches surrounded at the base by a few persistent bud-scales (Fig. 1). These deciduous leafy shoots may be compared superficially with the so-called dwarf shoots or foliage-spurs of pines with two, three or five needles : in the ginkgoalean trees the leaves were usually broader and flatter, and more of them on each dwarf shoot.

For the last sixty years, the name Phonicopsis has been widely adopted for specimens of flat, linear, multi-veined leaves borne on very short shoots, or preserved singly. The generic name denotes a certain external form and venation, not a particular anatomical structure. Florin has now been able to assign certain distinctive types of leaves having the external form of species of Phonicopsis to genera founded on anatomical character. One of these genera is Stephenophyllum, called after Cape Stephen on the south coast of Franz-Josef Land, where the best material was found. Seven leaves are borne on a diminutive axis surrounded by small, persistent bud-scales: such a shoot is comparable to the short branches of Ginkgo biloba, but differs in being much shorter and deciduous. Stephenophyllum is assigned to the Ginkgo family on the ground of similarity in certain important anatomical characters of diag. nostic value. Another genus is Culgoweria, named after Culgower in Sutherland, a locality from which some linear leaves of the same form were originally described as a species of Phonicopsis. This genus closely resembles Stephenophyllum in habit, but is distinguished by anatomical characters. A third genus, Windwardia (Fig. 1), differs from the other two in the absence of secretory ducts and in certain anatomical features. There are five leaves on each dwarf shoot. Among other new genera are Sphenobaiera and Arctobaiera, represented by leaves having the external form of the old genus Baiera, a name used for deeply dissected leaves, in some instances resembling the foliage of Ginkgo in outline, but with narrower lobes and without a leaf-stalk. In Arctobaiera the leaves were borne in tufts; some of them are divided in the distal portion into two narrow lobes. The genus Spheno. baiera, founded on a piece of leaf with tissues excellently preserved, differs in the greater degree of lobing and in anatomical characters. Another genus represented in the arctic flora is Czekanow. skia, a world-wide type, characterized by still narrower leaves once or twice deeply forked, borne in bunches on a dwarf shoot.

The important point is that Florin has demonstrated by his skilful handling of the material that the ginkgoalean group was represented by at least six genera in the Wealden flora of Franz-Josef Land. As Dr. Florin says, the genera "show clear affinities to Ginkgo, whereas they exhibit such great morphological and anatomical differences in comparison with other recent and fossil gymnosperm groups that no near relationship with them can be assumed".

Additional evidence of the former abundance and variety of trees of the Ginkgo family in arctic floras has been furnished by Prof. T. M. Harris of Reading in a series of remarkable papers, published in the Meddelelser om Gronland during the last ten years, on the Rhætic flora of Scoresby Sound on the east coast of Greenland (lat. $70^{\circ}$ $25^{\prime}$ N.). This exceptionally rich flora affords a most 
impressive example of the problem of climatic conditions raised by arctic fossil plants. Prof. Harris has been able to distinguish many species of Ginkgo (or Ginkgoites) by an examination of the epidermal structure of the leaves. He has also described species of Czekanowskia, Baiera, Phœnicopsis, and Torellia, a ginkgoalean genus previously recorded from Grinnell Land, still farther north ; together with a new generic type which he has named Hartzia.

It is noteworthy that several species of these different members of the Ginkgoales recorded from Mesozoic floras north of the Arctic Circle are either identical with or closely allied to species previously described from Europe and the Far East.

The genera already mentioned do not exhaust the list of ginkgoalean trees discovered in Mesozoic floras of the world : we are concerned only with arctic forms.

The two photographs, Fig. $2(a)$ and $(b)$, for which I am indebted to Dr. Florin, illustrate the striking similarity in the stomatal apparatus of a fossil leaf and a leaf of the existing species. In both preparations of the epidermal film there is the same general arrangement of subsidiary cells encircling the stomatal pore. The thick black bands mark the position of strongly cuticularized cell walls. Fig. $2(a)$ shows the epidermal structure of a leaf of Ginkgo adiantoides from Upper Tertiary beds (Pliocene) near Frankfort-onMain : Fig. $2(b)$ is from a leaf of Ginkgo biloba. The Frankfort leaves and others recorded from Pliocene beds in the Rhone Valley prove the existence of Ginkgo in Europe so late as the latter part of the Tertiary period shortly before the beginning of the Great Ice Age. We know that Ginkgo was a member of an early Tertiary (Eocene) flora on the basaltic plateau of which the Island of Mull is a detached fragment. The Ginkgo leaves from Mull in the Starkie Gardner collection in the British Museum
(Natural History) are exceptionally beautiful examples of fossil foliage.

We cannot say with certainty when the Ginkgo family first appeared in the vegetation of the world; there is, however, some evidence of its existence as early as the Permian period. We know that it had reached an advanced stage of development before the end of the Triassic period in both the northern and the southern hemisphere. The family continued to occupy a prominent position almost throughout the world in the Jurassic and in the early part of the Cretaceous

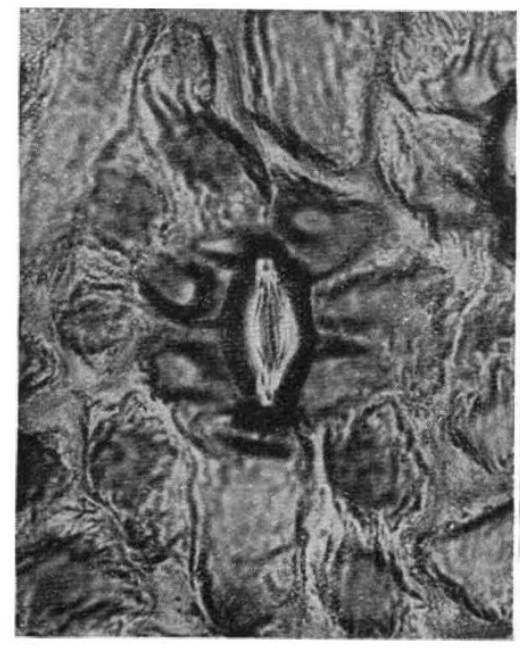

(a)

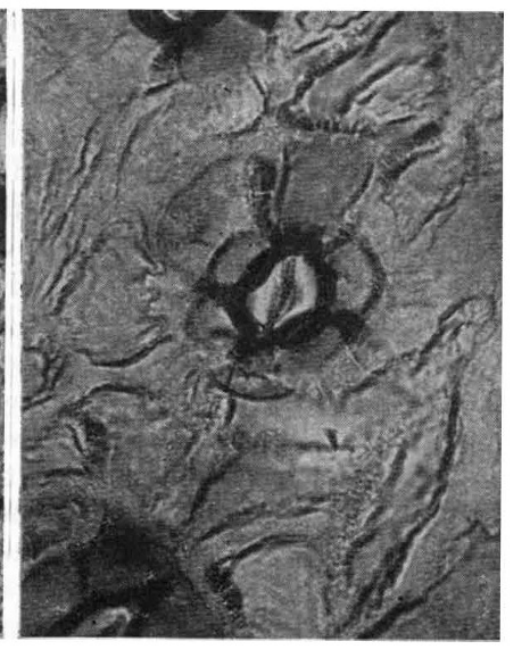

(b)

Fig. 2.

Stoma AND ADJACENT Cells on the lower SURfaCe of a leaf of (a) Ginkgo adiantoides (UNGER) HEER; (b) Ginkgo biloba L. $\times 400$. AFTER R. FLORIN.

period. The genus Ginkgo persisted as a widely distributed tree well into the Tertiary era.

This brief account may serve to give point to Darwin's description of the maidenhair tree as "a living fossil", and especially to emphasize the fact that this sacred tree is the solitary living representative of a large company of genera which played a conspicuous part in the vegetation of the world through successive geological periods.

\footnotetext{
${ }^{2}$ Contrib. Biol. Lab. Sci. Soc. China, 8, No. 3, 3 (1933).

${ }^{2}$ Palaeontographica, 81 and 82 , Abt. B. (1936).
}

\section{The Nottingham Meeting of the British Association}

$\mathrm{T}^{\mathrm{H}}$ HE preliminary programme of the British Association meeting at Nottingham has been issued, and is obtainable from the offices of the Association at Burlington House, London, and at Commerce Chambers, Elite Building, Nottingham.
The meeting will be held on September 1-8, and Sir Edward Poulton will be the president.

This will be the third time the Association has met in Nottingham. In 1866, the versatile Queen's Counsel and fellow of the Royal Society, William 